\title{
Determination of ethinylestradiol and levonorgestrel in oral contraceptives with HPLC methods with UV detection and UV/fluorescence detection
}

\author{
Zorica Arsova-Sarafinovska1*, Liljana Ugrinova², Katerina Starkoska1, \\ Dragan Djordjev¹, Aneta Dimitrovska² \\ ${ }^{1}$ Republic Institute for Health Protection, Skopje, Macedonia \\ ${ }^{2}$ Faculty of Pharmacy, Center for Drug Quality Control, Skopje, Macedonia
}

Received April 2006 , accepted June 2006

\begin{abstract}
Oral contraceptives are pharmaceutical formulations containing an estrogen in a small amount and a synthetic progestin in 5-30 times bigger amount. A sensitive, accurate and rapid method for determination of active compounds is required.

We have developed HPLC methods for determination of ethinylestradiol (EED) and levonorgestrel (LNG) in commercially available tablets. Chromatographic separation was performed on a Purospher ${ }^{\circledR}$ STAR RP-18e reversed-phase column (150 X 4.0 mm I.D.; particle size $5 \mu \mathrm{m}$ ) in an isocratic mode with a mobile phase constituted of $47 \%$ acetonitrile: $53 \%$ water (V/V) for both methods. The elution was carried out at a flow rate of $1.50 \mathrm{ml} / \mathrm{min}$. All analyses were performed at room temperature $\left(24+/-2^{\circ} \mathrm{C}\right)$. In the HPLC method with UV detection (internal standard method) both compounds were detected at $215 \mathrm{~nm}$. Drospirenone was used as an internal standard. In HPLC method with UV/fluorescence detection (external standard method) LNG was monitored at $242 \mathrm{~nm}$, while EED was detected with fluorescence detector at $310 \mathrm{~nm}$ (excitation $285 \mathrm{~nm}$ ).

The methods' performances were fully validated by a determination of linearity, reproducibility, accuracy and sensitivity. Both methods were applied for determination of Uniformity of Dosage Units. The results obtained with both methods were highly comparable. However, the HPLC method with UV/ fluorescence detection has showed superior sensitivity for EED indicated by 83 times lower detection limit.

HPLC method with UV/ fluorescence detection could be recommended as a method of choice for determination of ethinylestradiol, present at a very low dosage level in low-dose oral contraceptives, that also contain bigger amount of synthetic progestin.
\end{abstract}

Key words: ethinylestradiol, levonorgestrel, high performance liquid chromatography, oral contraceptives

Oral contraceptives are pharmaceutical formulations containing steroid hormones in a relatively small amount. The most commonly encountered estrogen is ethinylestradiol (Fig. 1), present at a very low dosage level (30-100 $\mu \mathrm{g}$ per tablet), in combination with an orally active synthetic progestin (one of the most commonly used is levonorgestrel (Fig. 2)), present at a level of 5 to 30 times that that of the estrogen. Ethinylestradiol (EED) is a semi synthetic

Tel:+389 (0)2 314 7070; Fax: +389 (0)2 3223354

*e-mail: zarsova2002@yahoo.co.uk

estrogen female sex hormone and levonorgestrel (LNG) is a synthetic steroid with an extremely potent progestational action $(1,2,3)$.

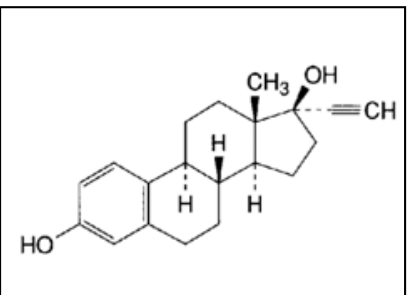

Fig. 1. Structure of ethinylestradiol (EED)

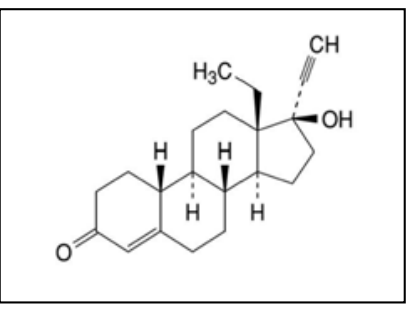

Fig. 2. Structure of levonorgestrel (LNG) 
Therefore, the modern low-dose oral contraceptives require a sensitive, accurate and rapid methods of quantitative determination which is unaffected by the small amount of the estrogen and the large excess of progestogen.

There are several reports (4-13) on determination of EED and LNG, including the use of derivative spectrometry (4), high performance liquid chromatography with fluorescence detection (5), gas chromatography-mass spectrometry on the pentafluorobenzoyl derivatives (6) and pentafluorobenzyltrimethylsilyl derivatives (7), solid phase extraction followed by gas chromatography /MS/MS after derivatization with mixture of $\mathrm{N}$-methyl-N-(trimethylsilyl)-trifluoroacetamide, trimethylsilylimidazole, and dithioerytrol (8), solid phase extraction followed by liquid chromatography-diode array detection-mass spectrometry $(9,10)$, affinity chromatography with tripeptide column (11), etc. Although the listed methods give high sensitivity, they still have drawbacks, including time consuming in extraction process when solid phase extraction is performed. Furthermore, the target analytes have to be derivatized if GS-MS is used which makes these procedures unsuitable for routine analysis. Additionally, spectrometry is susceptible to much interference of excipients, degradation products, and impurities.

On the contrary, liquid chromatography (LC) has only been employed in a few occasions $(12,13)$ regardless of its advantages over the already mentioned techniques. Thus, unlike GC-MS, LC enables determination of steroid without derivatization and it is not limited by such factors as properties of the substances (non volatile) and high molecular weight.

The aim of this research was standardization of HPLC methods for quantitative determination of associations of ethinylestradiol (ETE) - levonorgestrel (LNG) in commercially available oral contraceptives.

\section{Experimental}

\section{HPLC instrumentation and conditions}

HPLC analyses were performed using a Schimadzu LC2010 chromatographic system (Schimadzu, Kyoto, Japan) consisting of a LC-20AT Prominence liquid chromatograph pump with DGU-20A5 Prominence degasser, a SPD-M20A Prominence Diode Array Detector, RF 10AXI fluorescence detector and a SIL-20 AC Prominence auto sampler. Data analyses were done using Class VP 7.3 Software.

Chromatographic separation was performed on a Purospher ${ }^{\circledR}$ STAR RP-18e reversed-phase column (150 X $4.0 \mathrm{~mm}$ I.D.; particle size $5 \mu \mathrm{m}$ ), in an isocratic mode with a mobile phase constituted of $47 \%$ acetonitrile: $53 \%$ water (VN).

The elution was carried out at a flow rate of $1.50 \mathrm{ml} / \mathrm{min}$. The injection volume was $10 \mu \mathrm{l}$. All analyses were performed at room temperature ( $24+/-2$ degrees $C)$. In the UV method the column effluent was quantified at a wavelength of $215 \mathrm{~nm}$ with drospirenone used as an internal standard. In the method with UV / fluorescent detection, LNG was quantified at a wavelength of $242 \mathrm{~nm}$, while EED was quantified with fluorescent detection (excitation $285 \mathrm{~nm} /$ emission $310 \mathrm{~nm}$ ).

\section{Preparation of solutions}

Commercially available samples, coated tablets containing $30 \mu \mathrm{g}$ of EED and $150 \mu \mathrm{g}$ of LNG, were used in this research. Levonorgestrel, ethinylestradiol and internal standard were supplied by Schering Deutschland GmbH (Berlin, Germany). HPLC-grade acetonitrile was from Merck (Darmstadt, Germany). Double-distilled water was used to prepare mobile phase solutions.

A solvent was prepared by mixing 60 volumes of acetonitrile and 40 volumes of water. An internal standard solution used in the HPLC method with UV detection was prepared by dissolving an appropriate amount of drospirenone in solvent in order to obtain final concentration of $50.0 \mu \mathrm{g} / \mathrm{ml}$.

All solvents and solutions for HPLC analysis were filtered through a membrane filter $(0.45 \mu \mathrm{m}$ pore size $)$ and vacuum degassed before use.

\section{Calibration curves}

Stock solution of EED was prepared by dissolving Ethinylestradiol standard substance ( $25 \mathrm{mg}$ ) with $100 \mathrm{ml}$ solvent in a 100-ml volumetric flask. Standard solutions were prepared by dilution of EED stock solution with solvent to obtain final concentrations ranging from $3.75 \mu \mathrm{g} / \mathrm{ml}-15.0$ $\mu \mathrm{g} / \mathrm{ml}$ (in the method with UV detection) and $0.6 \mu \mathrm{g} / \mathrm{ml}-$ $3.0 \mu \mathrm{g} / \mathrm{ml}$ (in the method with UV / fluorescence detection).

Stock solution of LNG was prepared by dissolving Levonorgestrel standard substance (65 mg) with $100 \mathrm{ml}$ solvent in a $100-\mathrm{ml}$ volumetric flask. Standard solutions were prepared by dilution of LNG stock solution with solvent to obtain final concentrations ranging from $18.75 \mu \mathrm{g} / \mathrm{ml}-75.0$ $\mu \mathrm{g} / \mathrm{ml}$ (in the method with UV detection) and $3.0 \mu \mathrm{g} / \mathrm{ml}-$ $15.0 \mu \mathrm{g} / \mathrm{ml}$ (in the method with UV / fluorescence detection).

\section{Sample preparation}

In the HPLC method with UV detection, internal standard method, each of 10 tablets was transferred in 5-ml volumetric flask and $4 \mathrm{ml}$ internal standard solution was added. The solution was heated at $60^{\circ} \mathrm{C}$ in an ultrasonic bath for 25 minutes, cooled and filtered through $0.45 \mu \mathrm{m}$ nylon syringe filter. $10 \mu \mathrm{l}$ of the clear solution was injected into chromatograph.

In the HPLC method with UV/ fluorescence detection, external standard method, each of 10 tablets was transferred in 25 -ml volumetric flask and $20 \mathrm{ml}$ solvent was added. 
The solution was heated at $60^{\circ} \mathrm{C}$ in an ultrasonic bath for 25 minutes, cooled, filled up with the solvent and filtered through $0.045 \mu \mathrm{m}$-nylon syringe filter. $10 \mu \mathrm{l}$ of the clear solution was injected into chromatograph.

\section{Recovery tests}

To study the accuracy of the proposed analytical methods, recovery tests were conducted using the standard addition method. To discover whether excipients interfered with the analysis, known amounts of standard were added to tablet formulation samples and the resulting mixtures were analyzed by the proposed methods. The percent of recovery was calculated using the calibration equation.

\section{Results and discussion}

\section{HPLC method with UV detection, internal standard} method

In the preliminary research, the absorption spectra of EED and LNG in solvent were studied. The UV spectrum characteristic of the EED presents two maxima, one at 215 $\mathrm{nm}$ and another at $280 \mathrm{~nm}$, due to $\pi \rightarrow \pi^{*}$ transitions in the aromatic ring (14). LNG shows a characteristic absorption maximum at $242 \mathrm{~nm}$ which arises from $\pi \rightarrow \pi^{*}$ transitions (in this case in the conjugated $\alpha, \beta$-unsaturated ketone (C=C-C (O)-C) at position 3 (23). As both analyzed compounds absorb almost equally at a wavelength of $215 \mathrm{~nm}$, this wavelength was chosen as the most adequate for a simultaneous detection of EED and LNG in a mixture.

British Pharmacopoeia (BP) (15) separation method for Ethinylestradiol and Levonorgestrel Tablets, two active components in contraceptive tablets, uses a reversed-phase column $(15 \mathrm{~cm} \times 4.6 \mathrm{~mm})$ packed with octadecyl silica gel (particle size $5 \mu \mathrm{m}$ ) and a mobile phase consisting of $49 \%$ acetonitrile and $51 \%$ water, with a flow rate of $1.5 \mathrm{ml}$ per minute and a detection wavelength of $215 \mathrm{~nm}$. 2-hydroxybiphenyl was recommended as an internal standard. As 2-hydroxybiphenyl was not available at the time of performing the analysis, we have modified the proposed method by choosing another substance as an internal standard.

There are a few substances cited in the literature as internal standards in the determination of EED and LNG, such as: buthyl-hydroxytoluene (16), hydrocortisone (17) and drospirenone (13). However, the results we have obtained with buthyl-hydroxytoluene and hydrocortisone were not satisfactory. Namely, the elution of hydrocortisone was too fast, and buthyl-hydroxytoluene showed low absorptivity at the wavelength of $215 \mathrm{~nm}$. Finally, drospirenone has fulfilled all conditions to be used as an internal standard.

Chromatograms that represent the separation of EED and LNG (with drospirenone as an internal standard) in mixed standard solution and sample solution with UV detection at wavelength of $215 \mathrm{~nm}$ are shown in Fig. 3. and Fig. 4, respectively.

System suitability test is an integral part of the liquid chromatographic method. System repeatability was estimated by 10 repeated injections of mixed standard solution at $100 \%$ of test concentration ( $7.5 \mu \mathrm{g} / \mathrm{ml}$ EED, $37.5 \mu \mathrm{g} / \mathrm{ml} \mathrm{LNG}$, $50.0 \mu \mathrm{g} / \mathrm{ml}$ IS). The variation in retention times among 10 replicate injections was very low with RSD values: $0.21 \%$ for EED, $0.22 \%$ for internal standard, and $0.23 \%$ for LNG. The variation in peak areas among 10 replicate injections was also low with RSD values: $0.39 \%$ for EED, $0.19 \%$ for internal standard, and $0.20 \%$ for LNG. These results are in accordance with European Pharmacopoeia (2). The data obtained from system suitability test are presented in Table 1 .

The linearity of EED and LNG were established from a series of standard solutions for both EED and LNG separately, with concentrations ranging from $50 \%$ to $250 \%$ of the test concentration. Good linearity was observed for both analyzed compounds ( $\mathrm{r}^{2}=0,9999$ for both EED and LNG). The limit of detection (LOD) and the limit of quantification (LOQ) were calculated according to ICH Guideline (18). LOD for EED was $0.0538 \mu \mathrm{g} / \mathrm{ml}$, while LOQ for

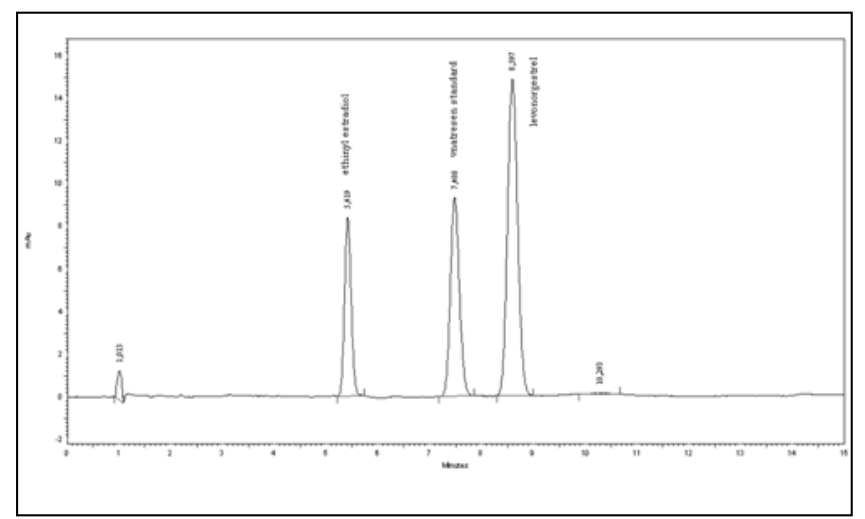

Fig. 3. A typical chromatogram of mixed standard solution (7.5 $\mu \mathrm{g} / \mathrm{ml}$ EED, $37.5 \mu \mathrm{g} / \mathrm{ml} \mathrm{LNG}$, and $50.0 \mu \mathrm{g} / \mathrm{ml}$ internal standard) detected by UV detector at a wavelength of $215 \mathrm{~nm}$

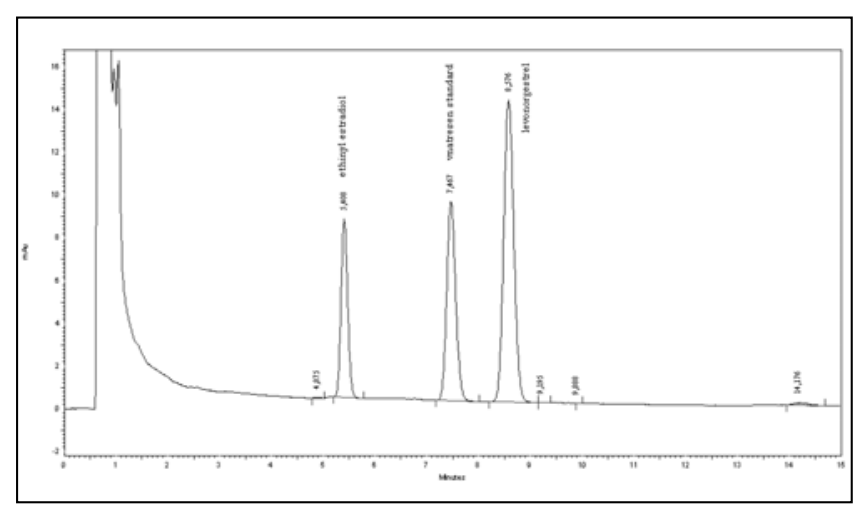

Fig. 4. A typical chromatogram of a sample solution detected by UV detector at a wavelength of $215 \mathrm{~nm}$ 
Table 1. System suitability test parameters, comparative data between two methods

\begin{tabular}{|c|c|c|c|c|c|}
\hline \multirow{2}{*}{$\begin{array}{c}\text { Method } \\
\text { Parameter }\end{array}$} & \multicolumn{3}{|c|}{ UV detection $^{1}$} & \multicolumn{2}{|c|}{ UV / fluorescence detection ${ }^{2}$} \\
\hline & EED & IS & LNG & EED & LNG \\
\hline Capacity factor $\left(k^{\prime}\right)$ & 4.349 & 6.392 & 7.487 & 4.147 & 7.027 \\
\hline Selectivity factor $(\alpha)^{3}$ & \multicolumn{2}{|c|}{$\alpha_{2 / 1}=1.470$} & $\alpha_{3 / 2}=1.171$ & \multicolumn{2}{|c|}{$\alpha^{\prime}{ }_{2 / 1}=1.694$} \\
\hline Theoretical plates & 3835 & 5607 & 6108 & 4175 & 6654 \\
\hline Resolution $^{4}$ & \multicolumn{2}{|c|}{$R_{2 / 1}=5.517$} & 2.640 & \multicolumn{2}{|c|}{$R_{2 / 1}^{\prime}=8.087$} \\
\hline Symmetry factor & 1.10 & 0.95 & 1.07 & 1.09 & 1.11 \\
\hline
\end{tabular}

1 HPLC method with UV detection at wavelength of $215 \mathrm{~nm}$ (for both levonorgestrel and ethinylestradiol), internal standard method

2 HPLC method with UV detection at wavelength of $242 \mathrm{~nm}$ (for levonorgestrel) and fluorescence detection at $310 \mathrm{~nm}$ (excitation at $285 \mathrm{~nm}$ ) (for ethinylestradiol), external standard method

$3 \alpha_{2 / 1}$ : selectivity factor between EED peak and IS (internal standard) peak; $\alpha_{3 / 2}$; selectivity factor between IS (internal standard) peak and LNG peak; $\alpha_{2 / 1}$; selectivity factor between EED peak and LNG peak;

${ }^{4} \mathrm{R}_{2 / 1}$ : resolution between EED peak and IS (internal standard) peak; $\mathrm{R}_{3 / 2}$ : resolution between IS (internal standard) peak and LNG peak; R'2/1: resolution between EED peak and LNG peak

Table 2. Linearity, comparative data between two methods

\begin{tabular}{ccccc}
\hline \hline & \multicolumn{2}{c}{ EED } & LNG \\
\hline & UV detection $^{1}$ & $\begin{array}{c}\text { UV / florescence } \\
\text { detection }^{2}\end{array}$ & $\begin{array}{c}\text { UV / florescence } \\
\text { detection }^{2}\end{array}$ \\
\cline { 2 - 5 } Concentration range $(\mathrm{i} \mathrm{g} / \mathrm{ml})$ & $3.75-18.75$ & $0.6-3.0$ & $18.75-93.75$ & $3.0-15.0$ \\
Slope & 4.4489 & 2213460 & 2.1364 & 21504 \\
\hline Intercept & 0.0276 & 9795 & 0.0113 & 1299.2 \\
Correlation coefficient $\left(\mathrm{r}^{2}\right)$ & 0.9999 & 1 & 0.9999 & 0.9998 \\
Limit of detection $(\mu \mathrm{g} / \mathrm{ml})$ & $5.38 \times 10^{-2}$ & $6.5 \times 10^{-4}$ & $7.84 \times 10^{-2}$ & $3.81 \times 10^{-2}$ \\
Limit of quantification $(\mu \mathrm{g} / \mathrm{ml})$ & 0.1629 & $1.97 \times 10^{-3}$ & 0.2378 & 0.1156 \\
\hline
\end{tabular}

1 HPLC method with UV det ection at wavelength of $215 \mathrm{~nm}$ (for both levonorgestrel and ethinylestradiol), internal standard method

2 PLC method with UV detection at wavelength of $242 \mathrm{~nm}$ (for levonorgestrel) and fluorescence detection at $310 \mathrm{~nm}$ (excitation at $285 \mathrm{~nm}$ ) (for ethinylestradiol), external standard method

Table 3. Precision, comparative data between two methods

\begin{tabular}{|c|c|c|c|c|}
\hline & \multicolumn{2}{|c|}{ UV detection $^{1}$} & \multicolumn{2}{|c|}{ UV / fluorescence detection ${ }^{2}$} \\
\hline & EED (ì g/tabl.) & $\%$ of label claim & EED (ì g/tabl.) & $\%$ of label claim \\
\hline $\bar{X}$ & 28.7372 & 95.79 & 28.9262 & 96.42 \\
\hline SD & 0.4643 & 1.5477 & 0.2588 & 0.8626 \\
\hline RSD (\%) & & 1.62 & & 0.89 \\
\hline \multirow[t]{2}{*}{ Confidence interval (95\%) } & \multicolumn{2}{|c|}{$\begin{array}{c}28.250-29.225 \text { ì g/tabl. } \\
94.17 \%-97.42 \%\end{array}$} & \multicolumn{2}{|c|}{$\begin{array}{c}28.654-29.198 \text { ì g/tabl. } \\
95.51 \%-97.33 \% \\
\end{array}$} \\
\hline & LNG (ì g/tabl.) & $\%$ of label claim & LNG (ì g/tabl.) & $\%$ of label claim \\
\hline $\bar{X}$ & 143.2109 & 95.47 & 141.3786 & 94.25 \\
\hline SD & 1.1562 & 0.7708 & 1.2835 & 0.8556 \\
\hline RSD (\%) & & 0.81 & & 0.91 \\
\hline Confidence interval (95\%) & \multicolumn{2}{|c|}{$\begin{array}{c}142.000-144.420 \text { ì g/tabl. } \\
94.67 \%-96.28 \%\end{array}$} & \multicolumn{2}{|c|}{$\begin{array}{c}140.030-142.73 \text { ì g/tabl. } \\
93.35 \%-95.15 \%\end{array}$} \\
\hline
\end{tabular}

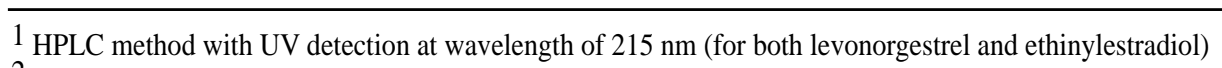

2 HPLC method with UV detection at wavelength of $242 \mathrm{~nm}$ (for levonorgestrel) and fluorescence detection at $310 \mathrm{~nm}$ (excitation at $285 \mathrm{~nm}$ ) (for ethinylestradiol) 
Table 4. Accuracy, comparative data between two methods

\begin{tabular}{ccccccc}
\hline \hline & & \multicolumn{3}{c}{ UV / fluorescence detection ${ }^{2}$} \\
\cline { 2 - 6 } & $\begin{array}{c}\text { Added amount detection } \\
(\mu \mathrm{g} / \mathrm{ml})\end{array}$ & $\begin{array}{c}\text { Found amount }^{3} \\
(\mu \mathrm{g} / \mathrm{ml})\end{array}$ & Recovery $(\%)$ & $\begin{array}{c}\text { Added amount } \\
(\mu \mathrm{g} / \mathrm{ml})\end{array}$ & $\begin{array}{c}\text { Found amount } \\
(\mu \mathrm{g} / \mathrm{ml})\end{array}$ & Recovery $(\%)^{3}$ \\
\hline EED & 1.84 & 1.79 & 97.37 & 0.308 & 0.307 & 99.93 \\
& 3.69 & 3.73 & 101.19 & 0.615 & 0.608 & 98.82 \\
& 5.53 & 5.60 & 101.25 & 0.923 & 0.925 & 100.20 \\
& 7.37 & 7.38 & 100.10 & 1.231 & 1.237 & 100.53 \\
& 9.21 & 9.13 & 99.08 & 1.539 & 1.536 & 99.85 \\
& 11.06 & 10.88 & 98.43 & 1.846 & 1.842 & 99.78 \\
$\bar{X} \pm$ SD & & $99.57 \pm 1.55$ & & & $99.85 \pm 0.57$ \\
RSD (\%) & & 1.56 & & & 0.58 \\
\hline LNG & 9.54 & 9.21 & 97.14 & 1.522 & 1.576 & 103.52 \\
& 19.08 & 19.43 & 100.48 & 3.044 & 2.989 & 98.19 \\
& 28.61 & 28.67 & 99.01 & 4.566 & 4.556 & 99.77 \\
& 38.15 & 38.00 & 98.68 & 6.088 & 6.058 & 99.51 \\
& 47.69 & 47.99 & 98.98 & 7.610 & 7.641 & 100.41 \\
$\bar{X} \pm$ SD & 57.23 & 56.97 & 99.96 & 9.132 & 9.138 & 100.06 \\
RSD (\%) & & & $98.86 \pm 1.19$ & & & $100.24 \pm 1.78$ \\
\hline
\end{tabular}

1 HPLC method with UV detection at wavelength of $215 \mathrm{~nm}$ (for both levonorgestrel and ethinylestradiol)

2 HPLC method with UV detection at wavelength of $242 \mathrm{~nm}$ (for levonorgestrel) and fluorescence detection at $310 \mathrm{~nm}$ (excitation at $285 \mathrm{~nm}$ ) (for ethinylestradiol)

3 Average of three determinations

EED was $0.1629 \mu \mathrm{g} / \mathrm{ml}$. LOD for LNG was $0.0784 \mu \mathrm{g} / \mathrm{ml}$, and LOQ for LNG was $0.2378 \mu \mathrm{g} / \mathrm{ml}$ (Table 2.).

The precision of the analytical method was assessed using 6 determinations at $100 \%$ of test concentration that were done on the same day, by the same analyst and using the same equipment. Intermediate precision was established by repeating the procedure in two different days by the same analyst. The relative standard deviations $(<2 \%)$ confirmed precision of the method. The statistical data are shown in Table 3.

The recovery tests were performed according to the recommendation of ICH Guideline (17). Satisfactory recoveries were observed for both EED and LNG (99.57\% $\pm 1.55 \%$, and $98.86 \% \pm 1.19 \%$, for EED and LNG, respectively). The results obtained are shown in Table 5 and they confirmed the accuracy of the method.

The proposed method was applied to analyze the parameter Uniformity of Dosage Units in the commercially available samples (coated tablets containing $30 \mu \mathrm{g}$ of ETE and $150 \mu \mathrm{g}$ of LNG). The obtained results were in good agreement with the certified values and were in accordance with European Pharmacopoeia requirements. The results obtained are shown in Table 5.

\section{HPLC method with UV/fluorescence detection, external} standard method

During the development of the analytical method for quantification of the active compound in Levonorgestrel and Ethinylestradiol tablet we have been faced with two inherent problems. They were: a) the low ultraviolet molar absorptivity of EED; and b) the low proportion of EED compared to LNG in the pharmaceutical formulation. Fortunately, the molecule of EED has ability to fluorescence (emit higher wavelength radiation) after excitation by shorter wavelength energy, which allowed us to measure the concentration of EED with fluorescence detector. On the contrary, levonorgestrel has no natural fluorescence. Because of that, we have chosen to measure the UV absorbance of levonorgestrel at $242 \mathrm{~nm}$ and the fluorescence of EED at $310 \mathrm{~nm}$ (excitation at $285 \mathrm{~nm}$ ) using a DAD detector connected in series with a fluorescence detector.

As the fluorescence detector is much more sensitive than UV detector (10-1000 times more sensitive, depending on the compound being measured), we had to dilute the sample solution to obtain the optimal test concentration. Preliminary tests were performed in order to define the concentration interval in which the intensity of the detector response is proportional to the concentration of the analyzed substance. Standard solu- 
tions of EED concentration ranging from $0.12 \mu \mathrm{g} / \mathrm{ml}-12.0$ $\mu \mathrm{g} / \mathrm{ml}$ were measured and the linearity was proven through the range $0.12 \mu \mathrm{g} / \mathrm{ml}-4.8 \mu \mathrm{g} / \mathrm{ml}$. Therefore, the concentration of $1.2 \mu \mathrm{g} / \mathrm{ml}$ was chosen as optimal test concentration.

A chromatogram that represents the separation of EED and LNG in mixed standard solution and sample with UV/ fluorescence detection is shown in Fig. 4. and Fig. 5., respectively.

System repeatability was estimated by 10 repeated injections of mixed standard solution at $100 \%$ of test concentration $(1.2 \mu \mathrm{g} / \mathrm{ml} \mathrm{EED,} 6.0 \mu \mathrm{g} / \mathrm{ml} \mathrm{LNG})$. The variation in retention times among 10 replicate injections was very low with RSD values: $0.37 \%$ for EED and $0.41 \%$ for LNG. The variation in peak areas among 10 replicate injections was also low with RSD values: $0.25 \%$ for EED and $0.23 \%$ for LNG. These results are in accordance with European Pharmacopoeia (2). The data obtained from system suitability test are presented in Table 1.

An excellent linearity was observed for both analyzed compounds ( $\mathrm{r}^{2}=1$ for EED and 0.9998 for LNG). The limit of detection (LOD) for EED was $0.00065 \mu \mathrm{g} / \mathrm{ml}$ and the limit of quantification (LOQ) for EED was $0.00197 \mu \mathrm{g} / \mathrm{ml}$. LOD for LNG was $0.0381 \mu \mathrm{g} / \mathrm{ml}$ (Table 2.).

It is obvious that HPLC method with fluorescence detection, external standard method, is about 83 times more sensitive for EED determination than HPLC method with UV detection, internal standard method $\left(\mathrm{LOD}_{\mathrm{FLUO}}=\right.$ $0.00065 \mathrm{~g} / \mathrm{ml}$ vs. $\mathrm{LOD}_{\mathrm{UV}}=0.0538 \mathrm{~g} / \mathrm{ml}$ ). Moreover, the use of wavelength of maximum absorbance for LNG detection (242nm) in the HPLC method with UV/fluorescence detection, external standard method, also enhances the sensitivity for LNG determination in comparison to the HPLC method with UV detection, internal standard method, where a wavelength of $215 \mathrm{~nm}$ is used $\left(\mathrm{LOD}_{242} \mathrm{~nm}=\right.$ $0.0381 \mu \mathrm{g} / \mathrm{ml}$ vs. $\left.\mathrm{LOD}_{215} \mathrm{~nm}=0.0785 \mu \mathrm{g} / \mathrm{ml}\right)$.

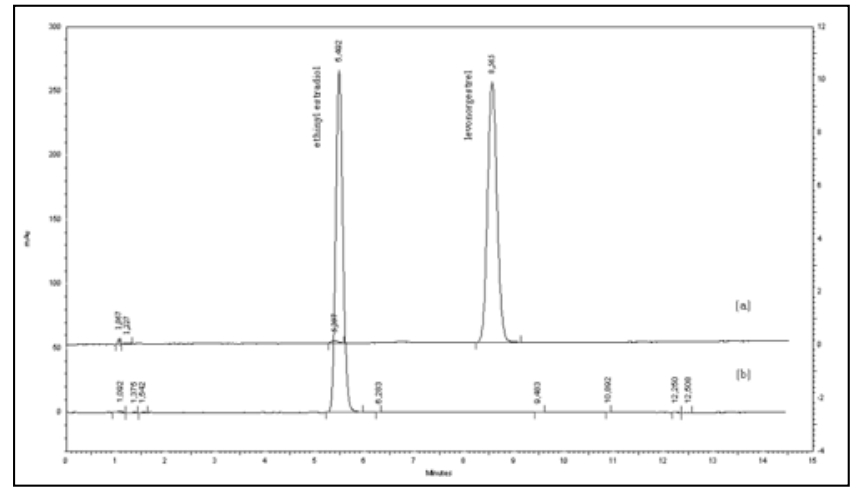

Fig. 5. A typical chromatogram of mixed standard solution $(1.2 \mathrm{mg} / \mathrm{ml}$ EED and $6.09 \mathrm{ptg} / \mathrm{ml} \mathrm{LNG})$ detected by UV detector at a wavelength of $242 \mathrm{~nm}$ (for LNG) and fluorescence detector at a wavelength of $310 \mathrm{~nm}$ (excitation at $285 \mathrm{~nm}$ ) (for EED)

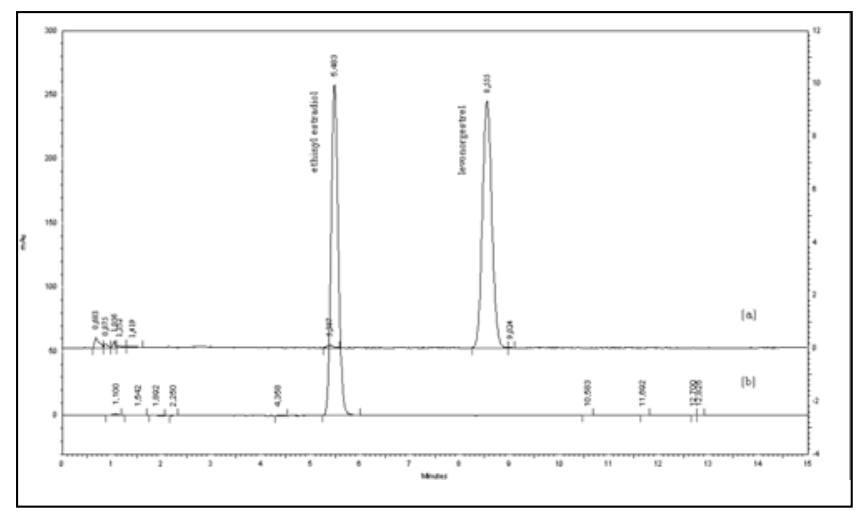

Fig. 6. A typical chromatogram of a sample solution detected by UV detector at a wavelength of $242 \mathrm{~nm}$ (for LNG) and fluorescence detector at a wavelength of $310 \mathrm{~nm}$ (excitation at $285 \mathrm{~nm}$ ) (for EED)

The precision of the method was validated by performing 6 determinations at $100 \%$ of test concentration that were done on the same day, by the same analyst and using the same equipment. Intermediate precision was established by repe-

Table 5. Uniformity of dosage units, comparative data between two methods

\begin{tabular}{ccccc}
\hline \hline & \multicolumn{2}{c}{ UV detection $^{1}$} & \multicolumn{2}{c}{ UV / fluorescence detection } \\
\cline { 2 - 5 } & EED (ì g/tabl.) & \% of label claim & EED (ì g/tabl.) & \% of label claim \\
\hline $\bar{X}$ & 28.5813 & 95.27 & 28.9087 & 96.36 \\
SD & & 2.29 & & 1.94 \\
AV & & 8.73 & & 6.78 \\
\hline & & \% of label claim & LNG (ì g/tabl.) & \% of label claim \\
$\bar{X}$ & LNG (ì g/tabl.) & 96.85 & 145.7140 & 97.14 \\
SD & 145.2815 & 1.38 & & 2.39 \\
AV & & 6.78 & 7.10 \\
\hline
\end{tabular}

1 HPLC method with UV detection at wavelength of $215 \mathrm{~nm}$ (for both levonorgestrel and ethinylestradiol)

2 HPLC method with UV detection at wavelength of $242 \mathrm{~nm}$ (for levonorgestrel) and fluorescence detection at $310 \mathrm{~nm}$ (excitation at $285 \mathrm{~nm}$ ) (for ethinylestradiol)

3 Average of three determinations 
ating the procedure in two different days by the same analyst. The variation in results obtained among 6 determinations was very low $(<2 \%)$, which confirmed precision of the method. The statistical data are shown in Table 3.

Satisfactory recoveries were observed for both EED and LNG $(99.85 \% \pm 0.57 \%$ and $100.24 \% \pm 1.78 \%$, for EED and LNG, respectively). The results are shown in Table 5.

The HPLC method with UV/ fluorescence detection, external standard method, was applied to analyze the parameter Uniformity of Dosage Units in the commercially available samples (coated tablets containing $30 \mu$ g of ETE and $150 \mu \mathrm{g}$ of LNG). The results were in good agreement with the declared values and in accordance with European Pharmacopoeia requirements. The results obtained are shown in Table 5.

\section{Conclusion}

Both of the proposed HPLC method enables simple, accurate, precise and rapid determination of EED and LNG in pharmaceutical dosage forms without interference from excipients and could, therefore, be easily adopted in routine quality control analysis. The methods' performances were fully validated by determination of linearity, reproducibility, accuracy and sensitivity. The methods were applied for determination of Uniformity of Dosage Units. The results obtained with both proposed methods were highly comparable. However, in the case of sensitivity, the HPLC method with UV/ fluorescence detection, external standard method, showed superior sensitivity, which was indicated by lower detection limit for EED and LNG. By applying fluorescence detection at $310 \mathrm{~nm}$ (excitation at $285 \mathrm{~nm}$ ) LOD for EED was about 83 times lower than with UV detection at 215 $\mathrm{nm}\left(\mathrm{LOD}_{\mathrm{FLUO}}=0.00065 \mu \mathrm{g} / \mathrm{ml} / \mathrm{LOD}_{\mathrm{UV}}=0.0538 \mu \mathrm{g} / \mathrm{ml}\right)$. Furthermore, we have also obtained a better sensitivity for LNG using a wavelength of maximum absorbance for LNG $(242 \mathrm{~nm})$ instead of a wavelength of $215 \mathrm{~nm}\left(\mathrm{LOD}_{242} \mathrm{~nm}\right.$ $=0.0381 \mu \mathrm{g} / \mathrm{ml} / \mathrm{LOD}_{215} \mathrm{~nm}=0.0785 \mu \mathrm{g} / \mathrm{ml}$ ).

The sensitivity of HPLC method with UV/ fluorescence detection is its main advantage and it could be recommended as the method of choice for determination of ethinylestradiol, present at a very low dosage level in low-dose oral contraceptives.

\section{References}

1. T.M. Dando and M.P. Curran, Drugs. 65, 2299-2306, (2005)

2. European Pharmacopoeia, $5^{\text {th }}$ Edition 2004, Council of Europe, Strasbourg, 2004, pp 1550-1551, 1911-1912

3. The Merck Index, Thirteenth Edition, Merck Co Inc, 2001, pp 666, 609.

4. J.J. Berzas, J.J. Rodriguez and G. Castaneda, Analyst. 122, 41-44 (1997)

5. R. Gatti, R. Gotti, M. G. Gioia and V. Cavrini, J Pharm Biomed Anal. 17, 337-347 (1998)

6. X.Y. Xiao, D.V. McCalley and J. McEvoy, J Chromatogr A. 923, 195-204 (2001)

7. S. Nakamura, T.H. Sian and S. Daishima, J Chromatogr A. 919, 275-282 (2001)

8. T.A. Ternes, M. Stumpf, J. Mueller, K. Haberer, R.D. Wilken and M. Servos, Sci Total Environ. 225, $81-90$ (1999)

9. L. Nygaard, H. Drohse Kilde, S.G. Andersen, L. Henriksen and V. Overby, J Pharm Biomed Anal. 34, 265-276, (2004)

10. T. Isobe, H. Shiraishi, M. Yasuda, A. Shinoda, H. Suzuki and M. Morita, J Chromatogr A. 984, 195-202 (2003)

11. C. Tozzi, L. Anfossi, G. Giraudi, C. Giovannoli, C. Baggiani and A. Vanni, J Chromatogr A. 966, 71-79, (2002)

12. S. H. Strusiak, J.G. Hoogerheide and M.S. Gardner, J Pharm Sci. 71, 636-640, (1982)

13. P.A. Lane, D.O. Mayberry and R.W.Young, J Pharm Sci. 76, 44-47, (1987)

14. M.J. Lopezde Alda and D. Barcelo, J Chromatogr A. 938, 145-153 (2001)

15. British Pharmacopoeia. London, UK: Constable \& Co Ltd., 2003, p. 2067-8, 2198-9

16. L. Havlikova, L. Novakova, L. Matysova, J. Sicha and P. Solich, J Chromatogr A. 143-149, (2006)

17. L. Novakova, L. Matysova, D. Solichova, M.A. Koupparis and P. Solich, J Chromatogr B Analyt Technol Biomed Life Sci. 813, 191-197, (2004)

18. International Conference on Harmonisation of Technical Requrements for Registration of Pharmaceuticals for Human Use. ICH Harmonised Tripartite Guideline: Validation of Analytical Procedures: Text and Methodology Q2 (R2) (2005) 


\section{Резиме}

\section{Определување на етинилестрадиол и левоноргестрел во перорални контрацептивни таблети со HPLC методи со UV и UV/флуоресцентна детекција}

Клучни зборови: етинилестрадиол, левоноргестрел, НРLC, перорални контрацептиви

Нискодозираните перорални контрацептиви содржат две активни компоненти: естроген хормон (присутен во многу мала количина) и синтетски прогестоген (присутен во 5-30 пати поголема количина). Заради ваквиот сооднос, потребен е сензитивен, точен и брз метод за истовремено определување на двете активни компоненти.

Развиени се HPLC методи за определување на етинилестрадиол (ЕЕД) и левонорегестрел (ЛНГ) во контрацептивни таблети. Раздојувањето на компонентите во двете методи беше изведено на реверзно фазна колона Рurospher ${ }^{\circledR}$ STAR RP-18e (150 X 4.0 mm I.D.; 5 нm), со мобилна фаза составена од 47\% ацетонитрил и 53\% вода (V/V), изократно, со брзина на проток - 1,50 ml /мин. Во HPLC методот со UV детекција (метод на внатрешен стандард) детекцијата на двете компоненти беше изведена на $215 \mathrm{~nm}$. Како интерен стандард беше употребен дроспиренон. Bo HPLC методот со UV/флуоресцентна детекција (метод на надворешен стандард), ЛНГ се детектира на $242 \mathrm{~nm}$, а ЕЕД со флуоресцентен детектор на $310 \mathrm{~nm}$ (ексцитација на $285 \mathrm{~nm}$ ).

Методите беа комплетно валидирани преку определување на линеарност, репродуцибилност, точност и сензитивност. Двата метода беа применети за определување на параметарот “воедначеност на дозирани единици”, при што се добиени споредливи резултати. Но, HPLC методот со UV/флуоресцентна детекција е многу посензитивен за определување на ЕЕД, што се потврдува со 83 пати пониската вредност на лимит на детекција за ЕЕД.

Ha HPLC методот со UV/флуоресцентна детекција му се дава предност како метод од избор при контрола на квалитетот на нискодозирани перорални контрацептиви со ЕЕД во комбинација со прогестогени активни компоненти, присутни во повисоки концентрации. 